\title{
The contribution of Dr. Jean-François Chamba to cheese science
}

The dairy industry, cheese researchers, and technologists have lost Dr. Jean-François Chamba who passed away on March 23, 2009.

Dr. Chamba was present at the foundation of the French Institute for Gruyère Cheese (ITG, now ACTILAIT) during the 1960s. The creation of this Institute underpinned a simple but deep thought: the major role that cheese quality plays in cheese markets. He insisted that a fundamental knowledge of cheese quality was the essential basis for technical action and that the precise scientific knowledge of technological mechanisms was a precondition to solving technical challenges and defects. Dr. Chamba explained that it was also necessary to have a deep and long-term knowledge of the quality in a cheese plant before being able to solve quality problems. Dr. Chamba developed two research areas that were closely connected: characterization of different cheese types and research on starters.

His first contribution involved technological research into the characterization of different cheese types. For example, Beaufort cheese was characterized by combining sensory, chemical, microbiological, and molecular analyses [4]. These methods were subsequently applied and focused on a wider number of cheeses, which ensured a good representativeness for each parameter studied.

Over 10 years, Dr. Chamba's team illustrated this in a series of studies on the technological parameters relevant to Emmental cheese-making. Ten ITG studies, published by ACTILAIT, constitute a unique collection of publications on one cheese type (see www.actilait.com). For each parameter, 30 cheese wheels were produced, with 10 replications for each level of the parameter. Impact on the final quality, cheese yield, and technology was analyzed and quantified. The parameters studied included: fat content, type of coagulating enzyme, coagulation time, gel firmness, curd grain size, cooking temperature, stirring rate, acidification rate, combinations such as draining $\times$ acidification, conditions of pressing, etc. Similar systematic studies have subsequently been performed on other cheese types $[1,7,11]$ : soft cheeses such as Reblochon, blue cheeses such as Fourme d'Ambert, semi-hard cheeses such as Tomme (Savoie and Pyrénées), etc.

Jean-François Chamba's publications on salting were a result of his work during his $\mathrm{Ph} . \mathrm{D}$. $[2,3]$ and showed the same preoccupation of representativeness and reproducibility. These publications constitute a technological anthology and ensure that continuity in the cheese know-how is maintained, which is not guaranteed for other cheese types.

His second contribution involved research on starters. The main advances in knowledge due to his work are now well known and commonly accepted, for example: the influence of temperatures that are used in cheese-making on acidification rates and the amino-peptidase activity of thermophilic lactic acid bacteria [9, 10, 12]; the strong interactions between lactobacilli and propionibacteria [5]; and the key role of propionibacteria on lipolysis and final aroma in propionic cheeses [8], and more generally, the role of starters in cheese [6].

But the most significant contribution of the Jean-François Chamba's work concerns his methodological approach: the capacity to analyze technological parameters, 
their interpretation in terms of stress on microorganisms, and the use of these stresses for designing practical microbiological selection methods that are easy-to-use, reproducible, discriminating, and validated in cheese technology.

What we learned from his research on starters is general because it involved relating the precise understanding of processing technologies with the behavior of microorganisms to create what would subsequently be called "technological simple models". Also, he highlighted the necessity to build links between the different aspects of cheese science and technology: researchers in chemistry and microbiology, cheese-makers, starter manufacturers, etc.

For current research and development activities in cheese and dairy science, the 40 years of scientific activity and publications by Jean-François Chamba constitute a clear overview that clearly identifies the place and role that a technical institute like ACTILAIT holds, laying between academic research and cheese factories, but with close relationships, as was Dr. Chamba, with scientists, starter manufacturers, and cheese-makers.

Florence Prost-Gorse Biomérieux

Jean-René Kerjean, Emmanuel Jamet

ACTILAIT

\section{REFERENCES}

[1] Bugaud C., Buchin S., Noel Y., Tessier L., Pochet S., Martin B., Chamba J.F., Relationships between Abondance cheese texture, its composition and that of milk produced by cows grazing different types of pastures, Lait 81 (2001) 593-607.

[2] Chamba J.F., Répartition du sel dans l'emmental. Relations entre la teneur en $\mathrm{NaCl}$ et la perception de la saveur salée, Sci. Alim. HS VIII (1987) 73-82.

[3] Chamba J.F., Salage de l'emmental : I. Influence des conditions de saumurage sur l'absorption du sel et sa cinétique, Lait 68 (1988) 121-142.

[4] Chamba J.F., Delacroix-Buchet A., Berdagué J.L., Clement J.F., Une approche globale de la caractérisation des fromages : l'exemple du fromage de Beaufort, Sci. Alim. 14 (1994) 581-590.

[5] Chamba J.F., Irlinger F., Secondary and Adjunct Cultures, in: Fox P.F., McSweeney P.L.H., Cogan T.M., Guinee T.P. (Eds.), Cheese: Chemistry, Physics and Microbiology, Vol. 1: General Aspects, 3rd Edn., Elsevier Academic Press, London, UK, 2004, pp. 191-206.

[6] Chamba J.F., Jamet E., Contribution to the safety assessment of technological microflora found in fermented dairy products - Introduction, Int. J. Food Microbiol. 126 (2008) 263-266.

[7] Chamba J.F., Martin B., Coulon J.B., Bugaud C., Effect of milk urea content on characteristics of matured Reblochon cheeses, Lait 77 (1997) 505-514.

[8] Chamba J.F., Perreard E., Contribution of propionic acid bacteria to lipolysis of Emmental cheese, Lait 82 (2002) 33-44.

[9] Chamba J.F., Prost F., Mesure de l'activité acidifiante des bactéries lactiques thermophiles utilisées pour la fabrication des fromages à pâte cuite, Lait 69 (1989) 417-431.

[10] Chopard M.A., Schmitt M., Perreard E., Chamba J.F., Aspects qualitatifs de l'activité protéolytique des lactobacilles thermophiles utilisés en fabrication de fromages à pâte pressée cuite, Lait 81 (2001) 183-194.

[11] Martin B., Chamba J.F., Coulon J.B., Perreard E., Effect of milk chemical composition and clotting characteristics on chemical and sensory properties of Reblochon de Savoie cheese, J. Dairy Res. 64 (1997) $157-162$.

[12] Prost F., Chamba J.F., Effect of aminopeptidase activity of thermophilic lactobacilli on Emmental cheese characteristics, J. Dairy Sci. 77 (1994) 24-33. 